\title{
Organizational culture and performance: The mediating roles of innovation capacity
}

\author{
Wen Hai Chih ${ }^{1}$, Ling Chu Huang ${ }^{1}$ and Tsung Ju Yang ${ }^{2 *}$ \\ ${ }^{1}$ Department of Business Administration, National Dong Hwa University, Da-Hsueh Rd, 97401, Shou-Feng, Hualien. \\ ${ }^{2}$ Department of Industries and Management, Minghsin University of Science and Technology, No.1, Xinxing Rd, 30401, \\ Xinfeng, Hsinchu.
}

Accepted 27 July, 2011

\begin{abstract}
This study highlights the service-dominant logic perspective of a firm's complex capability. The links between the functions of marketing strategies and distinctive capabilities indicate the importance of service management innovation, and emphasize the conceptualization of a service economy to verify the model. The model proposed in this study examines the relationships among market orientation, interaction orientation, innovativeness, innovative capacity, and performance, which includes customer performance and financial performance. This study presents empirical results from 225 larger-sized service firms in Taiwan. First, the organizational culture factors positively affecting innovative capacity include market orientation, interaction orientation and innovativeness. Innovative capacity in turn has a positive effect on performance. Secondly, ranked in order of effect on financial performance, these variables are innovative capacity, interaction orientation, market orientation and innovativeness. Finally, the mediating effects of customer performance partially increase the total effect of innovative capacity on financial performance.
\end{abstract}

Key words: Service-dominant logic, market orientation, interaction orientation, innovativeness, innovative capacity, performance.

\section{INTRODUCTION}

Company objectives can be the target of a firm's strategy, processes, structure, behaviors and organizational culture (Hurley and Hult, 1998). The deepest manifesttations of market and learning orientations appear at the cultural level (Schein, 1985), where culture is a set of shared assumptions about organizational functioning (Deshpandé and Webster, 1989). The competitive firm

\footnotetext{
${ }^{*}$ Corresponding author. E-mail: morgan4117@gmail.com. Tel: $+886-3-5593142 * 6965$
}

Abbreviations: RBV, Resource based view; CCIS, China credit Information Service Limited; SC, service-dominant; CFA, confirmatory factor analysis; AVE, average variance extracted; CR, composite reliability; GFI, goodness of fit index; NFI, normed fit index; CFI, comparative fit index; RMSR, root mean square residual; SEM, structural equation modeling; MLE, maximum likelihood estimation. uses culture to unify organizational capabilities into a cohesive whole (Day, 1994). In other words, culture is a complex of value specification, behavior reinforcement, and creation of organizational processes that produces basic assumptions (Schein, 1985). According to the resource based view (RBV), there are two driving capabilities in a dynamic market. The first involves marketoriented firm activities, where market orientation is a set of specific behaviors and activities (Kohli and Jaworski, 1990), a resource (Hunt and Morgan, 1995), a basis for decision making (Shapiro, 1988), or an aspect of organizational culture (Day, 1994; Deshpandé et al., 1993; Slater and Narver, 1995). There are two main perspectives on market orientation: a behavioral and a cultural perspective. The second driving capability is the customer-led firm acquirement underlying belief on customized perspective, which includes the application of process practice to develop a comprehensive construct (Homburg and Pflesser, 2000). Interaction orientation 
involves an underlying belief, relevant processes, and practices. However, interaction orientation differs from market orientation in terms of distinctive capability (Ramani and Kumar, 2008). According to Deshpandé et al. (1993), market orientation is the customer-led method of intentionally creating superior customer values. Therefore, market orientation and interaction orientation are both types of organizational culture.

Market-oriented or customer-led firm efforts to achieve the marketing concept of co-creation value on firm/ customer (Vargo and Lusch, 2004) require complex capabilities to successfully create innovation. Only through updates and replacement can firms avoid dysfunctional rigidity effects (Atuahene-Gima, 2005). Based on the managerial challenges of inter-firm knowledge transfer, absorptive capacity is a major source of competitive advantage (Zahra and George, 2002). The innovative capacity is related to what Cohen and Levinthal (1990) called absorptive capacity. Furthermore, innovative capacity is closely related to organizational culture (Hurley and Hult, 1998). For firms wishing to establish driving capability, the toughest managerial challenge is sustaining a competitive advantage (Abell, 1999). Firms have recently faced a strategic dilemma in developing new customized products or services. Atuahene-Gima (2005) showed that exploiting existing competencies may provide short-term benefits, but ultimately becomes a hindrance to the firm's long-term viability by stifling the exploration of new competencies (March, 1991; Levinthal and March, 1993). Although, many firms are adept at exploiting existing capabilities, they appear to falter when developing new ones (Reilly and Tushman, 2004). Leonard-Barton (1992) aptly termed this phenomenon the capability-rigidity paradox, in which the exploitation of existing competencies tends to crowd out the exploration or development of new ones. Scholars have posited that such a market-oriented (that is, customer-led) cultural factor may appear at various levels in an organization (Day, 1994; Hurley and Hult, 1998; Hult and Ketchen, 2001).

The RBV indicates that market orientation is a distinctive capability of the organization (Day, 1994). Interaction orientation is a composite of the concurrent capabilities that a firm collaborates with customer (Ramani and Kumar, 2008). The current debate suggests that customer relationship is probably more complex than previously depicted (Christensen and Bower, 1996; Slater and Narver, 1998; Slater and Narver, 1999), no doubt demanding further discussion. To supplement previous studies and lack of integrity, previous empirical studies have rarely discussed the intermediary impact between the service (Lukas and Ferrell, 2000). This study uses the cultural factors of market-oriented (that is, customer-led) firms (Homburg and Pflesser, 2000), the role of innovative capacity in spanning (Hurley and Hult, 1998), and customer competence (Prahalad and Ramaswamy, 2000) to attempt to obtain the firm's position advantage (Hult and Ketchen, 2001). This study refers to the antecedents of innovative capacity and the concept involved in innovation as it relates to organizational performance. Distinctive capabilities include market orientation, interaction orientation, innovativeness, and innovative capacity. Secondly, benchmarking firms combine the culture of the organization with the innovative capacity to further customer relationships and improve organizational performance. In this study, the authors attempted to use business process reengineering to verify the relationships between the complex capabilities and performance in a management innovation process (Vargo and Lusch, 2004). Marketing researchers rarely discuss these relationships. Conversely, this study combines the culture of an organization with innovative concepts, which supports the basis of power literature (Hurley and Hult, 1998). This study also considers the concept of service-dominant logic (S-D logic) of cocreation value on firm/customer (Vargo and Lusch, 2004), in which the role of spanning based on Atuahene-Gima (2005) suggests the competitive perspective and Day's (1994) spanning theory. The dual theory as a spanning capability promotes innovative capacity to converge these two factors. The research results make both an academic and practical contribution.

\section{CONCEPTUAL DEVELOPMENT}

The conceptual model of this study is shown on Figure 1.

\section{Market orientation}

Recently, the concept of market orientation demonstrated various aspects. According to the literature on marketing concepts has examined the extent to which firms either behave, or inclined to behave (Kohli and Jaworski, 1990). Two perspectives on market orientation can be distinguished, a behavioral and a cultural perspective (Homburg and Pflesser, 2000). The behavioral perspective concentrates on organizational activities related to the generation, dissemination, and responsiveness to market intelligence (Kohli and Jaworski, 1990). The cultural perspective focuses on organizational norms and values that encourage behaviors (Narver and Slater, 1990; Deshpandé et al., 1993). The RBV of market orientation is that a firm level's valuable, rare, socially complex, and inimitable resources (Day, 1994; Hunt and Morgan, 1995). Such the heterogeneity of resources across firms explains their comparative differences and competitive advantage in the marketplace (Barney, 1991). Otherwise, market orientation is also a decision-making process (Day, 1994), which means that market-oriented (that is, customer-led) firm gathers market intelligence process of their customers and competitors. Day (1994) suggested that market intelligence from the external links spanning process (strategic planning), that is the outside 


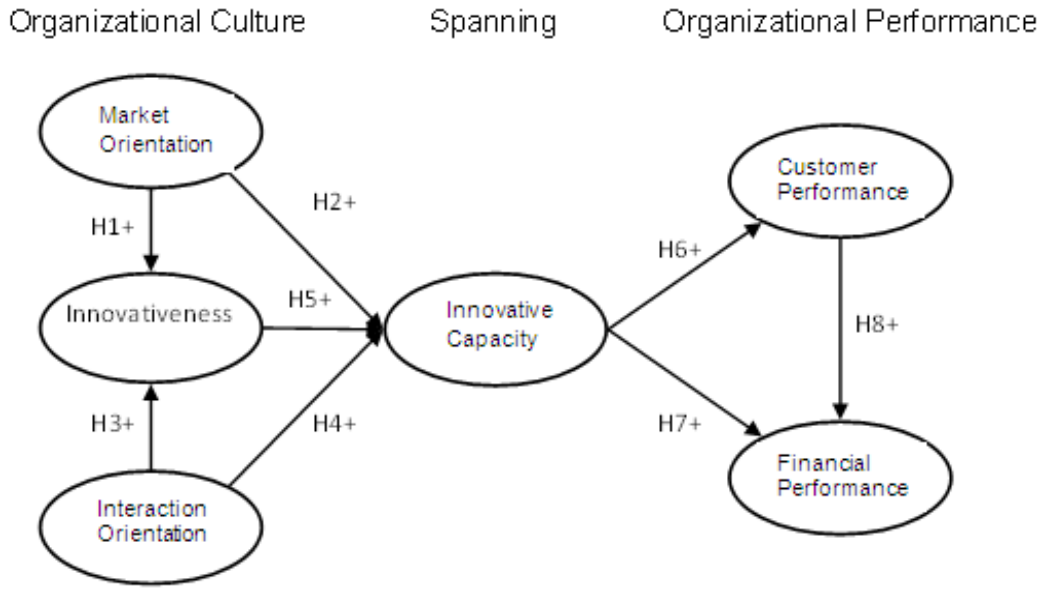

Figure 1. The conceptual model.

in capabilities connect the processes. Therefore, the importance of a market-oriented (that is, customer-led) firm culture is crucial to both managers and scholars (Deshpandé and Webster, 1989; Narver and Slater, 1990; Day, 1992; Menguc and Auh, 2006). Overall, market orientation is valuable because it forces the organization to continuously collect information on the needs of their target-customers and the capabilities of their competitors. The organizations then use this information to create superior customer value. Studies developed the nature of comprehensive theories and consequences of a market orientation (Shapiro, 1988; Kohli and Jaworski, 1990; Narver and Slater, 1990). The definition of market orientation is the ability of an organi-zation to gather information about customers and com-petitors through inter-functional coordination. This creates a type of excellent customer value on the organizational culture. Whereas it implies a market-oriented (that is, customerled) firm operation takes a long time to shape the culture in areas such as customer orientation, competitor orientation, and inter-functional coordination.

\section{Interaction orientation}

Interaction orientation is the evolution of product orientation, sale orientation to market orientation by firm adoption (Vargo and Lusch, 2004), and advanced individual customer-led concept (Ramani and Kumar, 2008). Cause technological advances increase interactivity between customers and firms, customers and customers, and firms and firms (Yadav and Varadarajan, 2005). Firms still need to produce superior products, sell smarter, and understand the entire market. In the future, the ability of firms to interact successfully with their indivi-dual customers will differentiate firms (Hoekstra et al., 1999; Reinartz et al., 2004). Ramani and Kumar (2008) proposed firms should focus on building interaction orientation, regardless of whether the competitive intensity is high or low. The customer-led firm could classify their customers, and concerned about the marketing activities of individual customer's interests. At the same time, customers expect firms to increase customization their products and services to meet their demands. The marketing concept of co-creation value on firm/customer called for a new marketing paradigm (Vargo and Lusch, 2004). The formation of interaction orientation concept, the RBV points out capabilities are complex with bundles of skills and accumulate knowledge exercise through organizational processes that enable firms to coordinate activities and make use of their assets (Day, 1994).

Organizational capability is a knowledge-based resource (Capron and Hulland, 1999), which refer to the processes and routines that a firm performs well (Slotegraaf et al., 2003). This perspective is in accordance with the proposal of Ramani and Kumar (2008) on interaction orientation. Therefore, the definition of interaction orientation is the development relevant process and routine practices (Homburg and Pflesser, 2000). The compositions encompass customer concept (underlying belief), interaction response capacity, customer empowerment (relevant processes), and customer value management (practices), which enables firms to remain competitive and perform better. Nevertheless, interaction orientation (Ramani and Kumar, 2008) is different from market orientation (Kohli and Jaworski, 1990; Narver and Slater, 1990) in that firms interaction oriented believe that individual customers and not a market is the unit of analysis. This study conducted marketing activities with the customer rather than for the customer, because customer-to-customer linkages are strategically important to the firms. Besides, both are a kind of organizational culture.

\section{Innovativeness}

Innovativeness is embedded in market-oriented or 
learning-oriented firms. The cultures of these firms is more exploratory, discovering the expressed and latent needs of customers (Slater and Narver, 1999), analyzing the knowledge sources of customer and competitor, and creating and delivering superior customer value as a priority (Narver and Slater, 1990). The organization-wide generation of market information pertains to target customers and their competitors, improving information acquisition, dissemination, and market response (Jaworski and Kohli, 1993). The goal of this approach is to achieve high performance for the firm (Slater and Narver, 1995). An organization's mission is to pursue market opportunities for the future. A firm based on innovation performance usually adopts or implements new ideas, products, and processes (Hurley and Hult, 1998). However, there is a broad concept of innovation that addresses the implementation of new ideas, products, or processes (Thompson, 1965).

The definition of innovation by Zaltman et al. (1973) is an idea, practice, or material artifact perceived as new by the relevant unit of adoption. Amabile et al. (1996) defined innovation as the successful implementation of creative ideas within an organization. Menguc and Auh (2006) defined innovativeness, using Hurley and Hult's (1998) concept of administrative innovation, as a firm's specification of organizational and management innovation. This concept includes the notion of openness to new ideas in a firm's culture. This is in accordance with Day's (1994) innovativeness concept in organizational culture or administrative innovation.

Hence, the deepest manifestations of market-oriented and learning-oriented appear at the cultural level (Schein, 1985). Organizations whose cultures emphasize innovation when resources are available tend to implement more innovations and develop competitive advantage. A firm with an innovative culture adopts or implements new ideas, products and processes through management innovation. The goal of this approach is to create superior customer value. Based on the above, this study defines innovativeness as a firm's receptivity to new ideas and innovation as part of its culture (Hurley and Hult, 1998).

\section{Innovative capacity}

In the driving market process, firms face a strategic dile$\mathrm{mma}$ in the development of customized new products or services. Exploiting competence may provide short-term success, but it can become a hindrance to the firm's longterm viability by stifling the exploration of new competencies (March, 1991; Levinthal and March, 1993). The innovative capacity is related to what Cohen and Levinthal (1990) called absorptive capacity (Hurley and Hult, 1998; Lichtenthaler, 2009). The number of innovations and organization is able to successfully adopt or implement can measure the definition of innovative capacity. The degree to which the culture within a firm is open to innovation, combined with its resources and other organizational characteristics, increases the capacity for innovation. Firms develop a greater capacity for innovation, develop a competitive advantage, and can achieve higher levels of performance (Day, 1994). AtuaheneGima (2005) stressed that innovative capacity is a measure of organizational capability and competitiveness. It is important to note that managers faces decisions regarding product innovation that exploit existing product innovation competencies, while avoiding the potential loss of exploring entirely new competencies.

A market-oriented (that is, customer-led) firm with customer orientation and competitor orientation can contribute to competence exploitation and competence exploration. Atuahene-Gima (2005) defined those capacities as organizations that invest in the pursuit of innovative products and services of knowledge, skills, and processes. This is in accordance with Day's (1994) thesis on capability perspective. Exploration competence refers to acquiring entirely new knowledge, skills, and processes. Exploitation competence refers to refining and extending its existing innovation (March, 1991). Based on the above, firms tend to enhance the two capabilities to increase the chances of simultaneous success (Levinthal and March, 1993). The complete innovative capacity, except for two important factors of competence exploitation and competence exploration while avoiding capabilityrigidity, organizations must learn to transform their capability of the knowledge, skill, and process. The definition of a market-oriented (that is, customer-led) firm with innovative capacity uses transformative learning to connect with the outside-in process. A large number of external specialties absorb the combinations of the complexes (Day, 1994; Lichtenthaler, 2009). Therefore, innovative capacity has both a spanning and a mediating role.

\section{Organizational culture as antecedent to absorptive capacity}

The innovation process includes two stages of initiation and implementation in market-oriented (that is, customerled) firm (Hurley and Hult, 1998). The initiation stage is an openness to innovation, in which determining the implementation stage relies on whether the members of an organization are willing to consider adopting or resisting innovation (Zaltman et al., 1973). The former is the notion of openness to new ideas as an aspect of a firm's culture. The latter is the organization's ability to successfully adopt or implement new ideas, processes, or products (Burns and Stalker, 1961). The competitive firm pursuit of innovation, according to the RBV and marketing theory suggestion, and Atuahene-Gima (2005) demonstrates that market orientation was a driving capability. Market-oriented (that is, customer-led) organizational culture factors can play this role (Hult and Ketchen, 2001). Hurley and Hult's (1998) conceptual model 
employs a combination of market orientation factors (organizational culture) and innovation (organizational outcome) as variables depicting how firms adapt, develop capabilities, and gain a competitive advantage. Innovation is the central mechanism by which organizations develop capabilities and adapt to their environments. According to Hurley and Hult's (1998) conceptual model, along with other aspects of organizational culture, functions serve as an antecedent to an innovation orientation. The results of the model indicate that firms use innovation to develop new products of services, and improve organizational performance better. Therefore, this study proposes hypotheses 1 and 2:

$\mathrm{H}_{1}$ : The organizational culture of market orientation has a positive effect on innovativeness.

$\mathrm{H}_{2}$ : The organizational culture of market orientation has a positive effect on innovative capacity.

The firm continued evolution and growth and the con-cept of customization. According to Deshpandé et al. (1993), market orientation is customer-led. This customer-led concept prioritizes customer interests to achieve longterm profit. Nevertheless, interaction orien-tation is unlike market orientation (Ramani and Kumar, 2008). Interaction-oriented firms view that individual customers (customer-led), and not the market (market-oriented), as the unit of analysis, and conduct marketing activities with the customer rather than for the customer. Customer-tocustomer linkages are strategically important to this type of firm. Interaction orientation also reflects the firm's ability to respond to individual custo-mers, helping it achieve profitable customer relationships by taking advantage of the information acquired through successive interactions (Ramani and Kumar, 2008). However, the processes practices implied the nature of interaction orientation such as an organizational culture. By increasing profit pressures, customers demand heterogeneity and advances in technology. Ramani and Kumar (2008) suggested that it is necessary for firms to develop an orientation that is appropriate for survival and success in interactive market environments. Interactions help firms increase their knowledge of customer taste and preference (Srinivasan et al., 2002). Previous research shows that the effective and efficient management of interactions and interfaces are sources for sustained competitive advantage (Rayport and Jaworski, 2005). This means that interaction orientation is connected to the innovation process. The two stages of the innovation process include initiation and implementation (Hurley and Hult, 1998). Based on the above, this study proposes hypotheses 3 and 4 :

$\mathrm{H}_{3}$ : The organizational culture of interaction orientation has a positive effect on innovativeness.

$\mathrm{H}_{4}$ : The organizational culture of interaction orientation has a positive effect on innovative capacity. Innovation is the generation, acceptance and implementation of new ideas, processes, products, or services (Thompson, 1965).

The implementation of innovation is identified as new based on the relevant unit of adoption (Garcia and Calantone, 2002). The innovativeness of the firm's culture acts in concert with various structural properties, which affects the innovative capacity of the organization. Innovativeness in an organization's culture facilitates the implementation of innovations (that is, innovative capacity) (Zaltman et al., 1973; Hurley and Hult, 1998). Firms with a greater capacity to innovate are better able to develop a competitive advantage, and can achieve higher levels of performance (Day, 1994). Therefore, this study proposes hypothesis 5 :

$\mathrm{H}_{5}$ : The organizational culture of innovativeness has a positive effect on innovative capacity.

\section{Consequences of innovative capacity}

Focus in the service industry, firms are increasingly relying on external knowledge to foster innovation and enhance their performance (Ireland et al., 2002; Zollo et al., 2002), including customer and financial performance (Kirca et al., 2005). Hurley and Hult's (1998) organization and market driven innovation model points out the innovative capacity to competitive advantage and performance. Innovative capacity is related to absorptive capacity (Cohen and Levinthal, 1990; Lichtenthaler, 2009). Due to the managerial challenges of inter-firm knowledge transfer, absorptive capacity is a major source of competitive advantage (Zahra and George, 2002). Such process-based capacity is a firm's ability to utilize external knowledge through the sequential processes of exploratory, exploitative, and transformative learning (Lane et al., 2006). Therefore, exploratory competence is the acquisition of external knowledge through potential absorptive capacity (Zahra and George, 2002). Exploitative competence involves the application of external knowledge through realized absorptive capacity (Zahra and George, 2002). Transformative learning links these two competences to maintaining knowledge over time (Garud and Nayyar, 1994). A process-based firm is better able to engage in innovation and achieve higher performance (Day, 1994). Based on the above, this study proposes Hypotheses 6 and 7:

$\mathrm{H}_{6}$ : Innovative capacity of services has a positive effect on customer performance.

$\mathrm{H}_{7}$ : Innovative capacity of services has a positive effect on financial performance.

\section{Customer performance and finance performance}

Superior relational performance leads to superior profit performance (Ramani and Kumar, 2008). Previous 
research relates customer satisfaction scores to increased patronage (Anderson et al., 2004). Conversely, negative word-of mouth behavior could have detrimental effects on the value of a firm's customer base (Hogan et al., 2003), whereas positive word of mouth is of great importance to a firm. Measures of customer-based relational performance, such as satisfaction and word of mouth, are positively related to measures of customerbased profitability (Reichheld, 2006). Therefore, this study proposes Hypothesis 8:

\section{$\mathrm{H}_{8}$ : Customer performance has a positive effect on financial performance.}

\section{METHODS}

\section{Sample, pretest and data collection}

This study collected a sample from the China Credit Information service Limited. (CCIS) published by the top 5000 largest corporations in Taiwan, which selects the top 2000 service firms. This study, according to Vargo and Lusch (2004), proposes S-D logic as a foundational premise with a focus on specific topics using the service economy. The service economy in Taiwan's companies creates management innovation activities. General services finance and information firms are typical representative of the service industry. This study mailed questionnaires to firms. To increase the return rate, we took the following steps: (1) According the latest corporation directory published in 2010 by CCIS , the questionnaires were directly sent to the general managers; (2) return letter to advertising; (3) research institutions, researchers and contacts were listed; (4) released in August to avoid releasing peak. Before mailing the questionnaires, this study used convenient sampling to select 60 service firm managers and 60 EMBA students. A pretest was conducted during May 2010. There were 118 valid samples. The results of the reliability analysis attained Cronbach's $\alpha(\alpha>0.7)$ coefficient standard in each dimension initiated a large-scale release.

\section{Measures}

The respondents of this study consisted of general managers. Except for the age, capital, employee, turnover, and listed/OTC company, the questionnaire used a Likert 7-point scale for the survey, with 1 indicating "strongly disagree" and 7 indicating "strongly agree". This study operates as a multidimensional construct the following: The definition of market orientation is the ability of an organization to gather customer and competitor information. To create superior customer values through inter-functional coordination an organizational culture. Three dimensions were based on Menguc and Auh (2006) included customer orientation (five items), competitor orientation (four items), and inter-functional coordination (five items). Interaction orientation is the development of relevant procedures and routine practices, to make use of information through successive interactions, to achieve profitable customer relationships. Items based on Ramani and Kumar (2008) included belief in the customer concept (three items), interaction response capacity (four items), customer empowerment (three items), and customer value management (three items). The definition of innovativeness is the culture of a firm with innovativeness to implement new ideas, product, or processes successfully.

The items based on Hurley and Hult (1998) included one dimension is innovativeness (five items). The definition of innovation capacity is the organizations invest in service innovation and the pursuit of knowledge, skills and processes, which converted to core competencies. Items based on both Atuahene-Gima (2005) and Lichtenthaler (2009) included competence exploitation (five items), competence exploration (five items), and transformative learning (eight items). A customer service-oriented firm evaluates the organizational performance by using subjective performance indicators to analyze firm-level performance. The items based on Kirca et al. (2005) included customer performance (three items) and financial performance (three items).

\section{ANALYSES AND RESULTS}

\section{Measure assessment}

This study mailed questionnaires to the top 2000 service firms in Taiwan. A total of $12.0 \%$ firm replied and the 225 $(11.2 \%)$ questionnaires were valid. Non-Response bias test was applied. Questionnaires based on received time, 75 and $25 \%$ were divided into two groups of before and after (Armstrong and Overton, 1977) and compared with basic data, including the age $(F=1.273)$, capital $(F=0.863)$, employees $(F=0.140)$, turnover $(F=0.988)$ and listed/OTC company $(F=0.115)$. The sample inference showed no significant difference between the two groups. The following is the basic data of this study. More than half of the service firms in the sample have been in operation for more than 21 years $(52.4 \%)$, and have capital of under 500 million NTD (56.0\%), turnover under 5 billion NTD (79.1\%), less than 500 employees (76.9\%). A smaller percentage was listed/OTC companies (23.5\%).

These results reflect the status of the larger service firms in Taiwan. We conducted reliability analysis on the measurement items. The Cronbach's a of the market orientation, interaction orientation, innovativeness, innovative capacity, customer performance and financial performance are $0.818,0.819,0.849,0.887,0.552$ and 0.750 , respectively, except for customer performance, which were all higher than the standard of 0.7 suggested by Nunnally (1978). This indicates that the internal consistency of measuring tools is good (Table 1).

The measurement of the validity in this study refers to the development of literature for theoretical basis. Practical and academic experts and the pretest were employed to evaluate and revise the measurement. This study had content validity. The sample size was consistent with Bagozzi and Yi (1988), who recommended a sample of no less than 200. In accordance with Anderson and Gerbing (1988), the analysis consisted of two steps. First, we used confirmatory factor analysis (CFA) to evaluate each variable. Except for customer performance was less than the standard value, the results indicated that the factor loading of all items was significant, with average variance extracted (AVE) between 0.527 0.732, which was higher than 0.5 , and composite reliability (CR) between 0.709 0.938, which was higher than 0.7. This study showed convergent validity of measurement items 
Table 1. The reliability of the variables examined.

\begin{tabular}{lccccccl}
\hline Variable & Item & Mean & Var. & $\boldsymbol{\alpha}$ & CR & AVE & Reference \\
\hline Market orientation & 14 & 6.1 & 0.43 & 0.818 & 0.918 & 0.791 & \\
Customer orientation & 5 & 6.3 & 0.38 & 0.827 & 0.890 & 0.620 & Menguc and Auh (2006) \\
Competitor orientation & 4 & 6.0 & 0.46 & 0.778 & 0.830 & 0.557 & \\
Inter-functional Coordination & 5 & 6.0 & 0.45 & 0.816 & 0.854 & 0.545 & \\
& & & & & & & \\
Interaction orientation & 13 & 5.7 & 0.76 & 0.819 & 0.860 & 0.606 & \\
Customer concept & 3 & 6.0 & 0.61 & 0.762 & 0.824 & 0.615 & Ramani and Kumar \\
Response capacity & 4 & 6.0 & 0.73 & 0.891 & 0.897 & 0.689 & (2008) \\
Customer empowerment & 3 & 5.6 & 0.82 & 0.712 & 0.834 & 0.633 & \\
Customer value & 3 & 5.4 & 0.88 & 0.769 & 0.709 & 0.646 & \\
& & & & & & & \\
Innovativeness & 4 & 5.8 & 0.64 & 0.849 & 0.867 & 0.627 & Hurley and Hult (1998) \\
& & & & & & & \\
Innovative capacity & 18 & 5.8 & 0.49 & 0.887 & 0.923 & 0.897 & Atuahene-Gima (2005); \\
Competence exploitation & 5 & 5.8 & 0.45 & 0.773 & 0.830 & 0.527 & Lichtenthaler (2009) \\
& & & & & & & \\
Competence exploration & 5 & 5.8 & 0.57 & 0.912 & 0.932 & 0.732 & \\
Transformative learning & 8 & 5.8 & 0.46 & 0.916 & 0.938 & 0.655 & Kirca et al. (2005) \\
Customer performance & 3 & 5.5 & 0.69 & 0.552 & 0.670 & 0.435 & \\
Financial performance & 3 & 5.7 & 0.62 & 0.750 & 0.785 & 0.552 & \\
\hline
\end{tabular}

Note. Var. $=$ Variance; $\alpha=$ Cronbach's $\alpha ; C R=$ composite reliability; $A V E=$ average variance extracted.

(Fornell and Larcker, 1981). Second, the variables were referenced with a number of indicators to measure fitness, including goodness of fit index (GFI), normed fit index (NFI), comparative fit index (CFI) higher than 0.9 , and root mean square residual (RMSR) less than 0.05 . The model showed good convergent validity. The discriminant validity of the measuring dimensions of construct suggested by Fornell and Larcker (1981). The result showed that the correlation between any two dimensions in this study was less than the AVE square of each dimension, which means that there is discriminant validity among these dimensions (Table 2).

\section{Hypotheses testing}

This study conducted structural equation modeling (SEM) with sample sizes between 100 and 400 (Hair et al., 2006). The SEM was conducted using maximum likelihood estimation (MLE). The goodness of fit index of the whole model of this study is $X^{2}=317.758$, d.f. $=161$, $X^{2} / \mathrm{df}=1.974, \quad \mathrm{GFI}=0.876, \quad \mathrm{CFI}=0.938, \quad \mathrm{RMSR}=0.052$, RMSEA $=0.066, \mathrm{NFI}=0.883$. A number of goodness of fit indexes fit the acceptable standard, which meant that the model fit was good. The study then examined the relationships among the constructs (Figure 2 and Table 3). An empirical study of the service economy in Taiwan found that the effects of market orientation were significant for both innovativeness and innovative capacity. The path coefficients were $0.437(p<0.001)$ and $0.249(p<0.01)$. This supported Hypotheses 1 and 2 of this study. The effects of interaction orientation were significant for both innovativeness and innovative capacity. The path coefficients were $0.377(p<0.001)$ and $0.422(p<0.001)$. Also this supported hypotheses 3 and 4 of this study. Next, the effect of innovativeness to innovative capacity was significant. The path coefficient was $0.357(p<0.001)$. Therefore, hypothesis 5 was supported. For the absorptive capacity, the effects of innovative capacity were significant for both customer performance and financial performance. The path coefficients were $0.790(p<0.001)$ and $0.380(p<0.01)$. This supported hypotheses 6 and 7 of this study. Finally, the effect of customer performance to financial performance was significant. The path coefficient was $0.468(p<0.01)$. Therefore, hypothesis 8 was also supported.

This study analyzes the effect of each antecedent on financial performance (Table 4), including direct and indirect effects. Among all of the antecedent variables of organizational performance in the service industry, the order of the total effect are innovative capacity, interaction orientation, market orientation, and innovativeness, among which the total effect of innovative capacity to financial performance is 0.750 , including direct effect 0.380 and indirect effect 0.370 . Next, the effect of interaction orientation and market orientation factors to financial performance are 0.417 and 0.304 , respectively. Finally, the effect of innovativeness to financial 
Table 2. Matrix of the related coefficients.

\begin{tabular}{|c|c|c|c|c|c|c|c|c|c|c|c|c|c|}
\hline Variable & 1 & 2 & 3 & 4 & 5 & 6 & 7 & 8 & 9 & 10 & 11 & 12 & 13 \\
\hline Customer orientation & $(0.787)$ & & & & & & & & & & & & \\
\hline Competitor orientation & $0.500^{*}$ & $(0.746)$ & & & & & & & & & & & \\
\hline Inter-functional coord. & $0.656^{*}$ & $0.647^{\star}$ & $(0.738)$ & & & & & & & & & & \\
\hline Customer concept & $0.467^{*}$ & $0.484^{*}$ & $0.484^{*}$ & $(0.784)$ & & & & & & & & & \\
\hline Response capacity & $0.443^{*}$ & $0.366^{*}$ & $0.371^{*}$ & $0.542^{*}$ & $(0.830)$ & & & & & & & & \\
\hline Customer empowerment & $0.494^{*}$ & $0.446^{*}$ & $0.498^{*}$ & $0.495^{\star}$ & $0.554^{*}$ & $(0.800)$ & & & & & & & \\
\hline Customer value & $0.397^{*}$ & $0.432^{*}$ & $0.490^{*}$ & $0.437^{\star}$ & $0.519^{*}$ & $0.636^{*}$ & $(0.804)$ & & & & & & \\
\hline Innovativeness & $0.501^{*}$ & $0.525^{\star}$ & $0.577^{*}$ & $0.476^{*}$ & $0.444^{*}$ & $0.548^{*}$ & $0.470^{*}$ & (0.791) & & & & & \\
\hline Competence exploitation & $0.551^{*}$ & $0.499^{*}$ & $0.619^{*}$ & $0.548^{*}$ & $0.434^{*}$ & $0.483^{\star}$ & $0.447^{*}$ & $0.667^{*}$ & $(0.726)$ & & & & \\
\hline Competence exploration & $0.504^{*}$ & $0.486^{*}$ & $0.590^{*}$ & $0.594^{*}$ & $0.438^{*}$ & $0.593^{*}$ & $0.482^{*}$ & $0.684^{*}$ & $0.752^{*}$ & $(0.856)$ & & & \\
\hline Transformative learning & $0.524^{*}$ & $0.522^{*}$ & $0.625^{*}$ & $0.559^{*}$ & $0.529^{*}$ & $0.607^{*}$ & $0.542^{*}$ & $0.697^{*}$ & $0.679^{*}$ & $0.744^{*}$ & $(0.809)$ & & \\
\hline Customer performance & $0.426^{*}$ & $0.441^{*}$ & $0.472^{*}$ & $0.419^{*}$ & $0.415^{\star}$ & $0.447^{*}$ & $0.375^{*}$ & $0.396^{*}$ & $0.497^{\star}$ & $0.499^{*}$ & $0.544^{*}$ & $(0.660)$ & \\
\hline Financial performance & $0.470^{*}$ & $0.386^{*}$ & $0.471^{*}$ & $0.464^{*}$ & $0.487^{*}$ & $0.580^{*}$ & $0.603^{*}$ & $0.435^{*}$ & $0.531^{*}$ & $0.541^{*}$ & $0.552^{*}$ & $0.517^{*}$ & $(0.743)$ \\
\hline
\end{tabular}

Note. Number in brackets is AVE square values; ${ }^{*} p<0.001$.

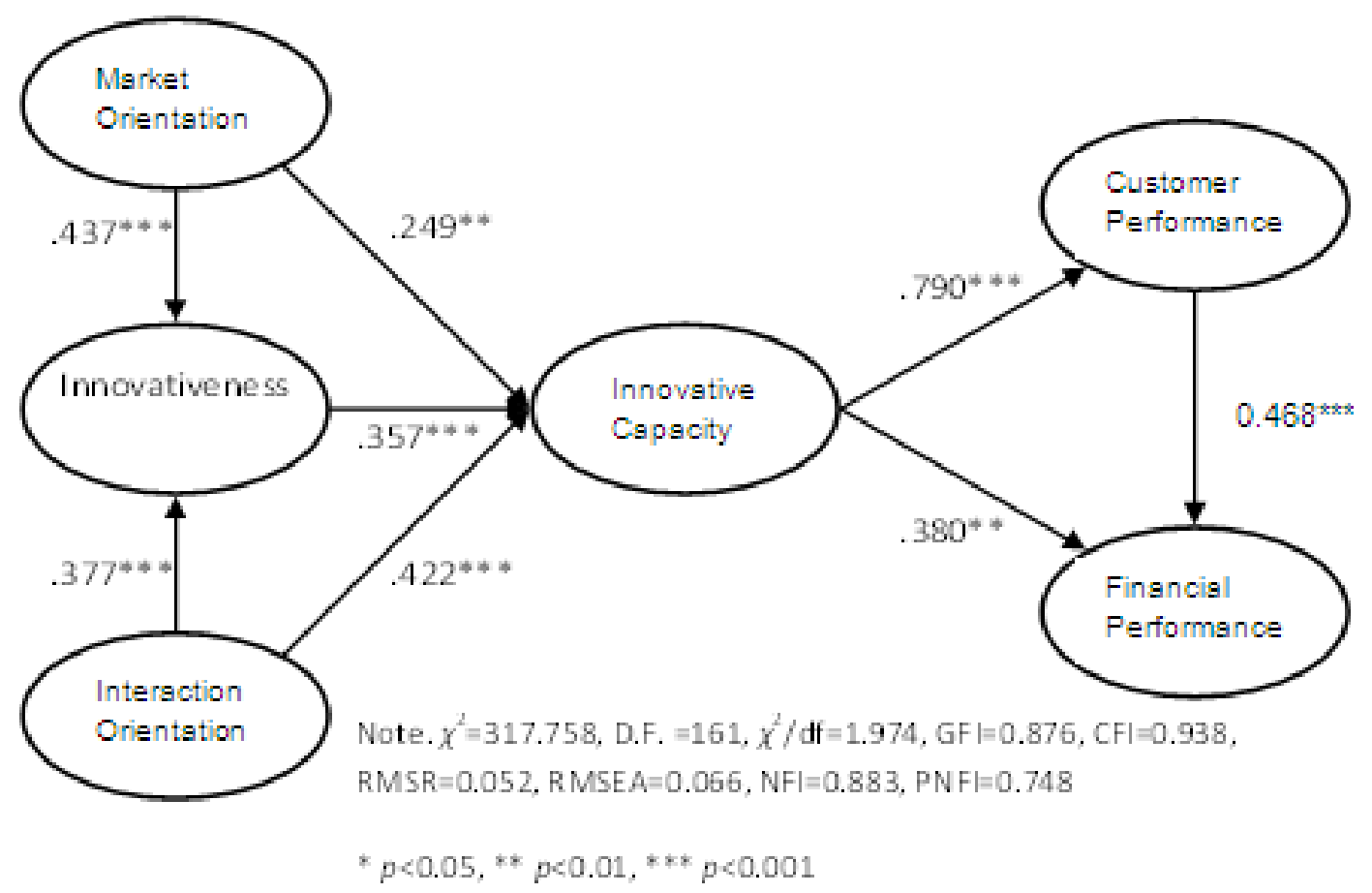

Figure 2. The structural model.

performance is 0.268 . The results show that innovative capacity and interaction orientation have the greatest effect on financial performance in the service industry. The results verified the previous marketing theories emphasizing that market-oriented (that is, customer-led) services are highly customization and subsequent costs (Anderson et al., 1997), which means that firms must simultaneously develop exploitation competence and exploration competence, and learning transforms into new market opportunities. Continuously interaction with individual customers can improve customer value and organizational performance. This results merit further discussion. Otherwise, the model (Figure 1) posits that innovative capacity mediate the effects of market orientation, interaction orientation and innovativeness on financial performance. This study used Baron and Kenny's (1986) tests of mediation to verify the relationships of the model. With the entry of innovative capacity, the effects of market orientation $(\beta=.516, p<.001)$ and interaction orientation $(\beta=.673, \quad p<.001)$ on financial. 
Table 3. Results of hypothesis testing.

\begin{tabular}{lcccccc}
\hline Hypothesis & \multicolumn{3}{c}{ Relationship } & Path & p-value & Result \\
\hline $\mathrm{H}_{1}$ & $\mathrm{MO}$ & $\rightarrow$ & INN & 0.437 & 0.000 & Supported \\
$\mathrm{H}_{2}$ & $\mathrm{MO}$ & $\rightarrow$ & IC & 0.249 & 0.003 & Supported \\
$\mathrm{H}_{3}$ & $\mathrm{IO}$ & $\rightarrow$ & INN & 0.377 & 0.000 & Supported \\
$\mathrm{H}_{4}$ & $\mathrm{I}$ & $\rightarrow$ & IC & 0.422 & 0.000 & Supported \\
$\mathrm{H}_{5}$ & INN & $\rightarrow$ & IC & 0.357 & 0.000 & Supported \\
$\mathrm{H}_{6}$ & IC & $\rightarrow$ & CP & 0.790 & 0.000 & Supported \\
$\mathrm{H}_{7}$ & IC & $\rightarrow$ & FP & 0.380 & 0.009 & Supported \\
$\mathrm{H}_{8}$ & $\mathrm{CP}$ & $\rightarrow$ & FP & 0.468 & 0.005 & Supported \\
\hline
\end{tabular}

Note. $\mathrm{MO}=$ market orientation; $\mathrm{IO}=$ interaction orientation; $\mathrm{INN}=$ =innovativeness; $\mathrm{IC}=$ =innovative capacity; $\mathrm{CP}=$ customer performance; $\mathrm{FP}=$ financial performance.

Table 4. Impacts on financial performance.

\begin{tabular}{lccc}
\hline Variable & Direct impact & Indirect impact & Total impact \\
\hline MO & - & 0.304 & 0.304 \\
IO & - & 0.417 & 0.417 \\
INN & - & 0.268 & 0.268 \\
IC & 0.380 & 0.370 & 0.750 \\
CP & 0.468 & - & 0.468 \\
\hline
\end{tabular}

Note. $\mathrm{MO}=$ Market Orientation; $\mathrm{IO}=$ interaction orientation; INN =innovativeness; $\mathrm{IC}=$ innovative capacity; $\mathrm{CP}=$ customer performance.

performance are remain significant but reduced: market orientation $(\beta=.187, p<.05)$ and interaction orientation $(\beta=.493, p<.001)$. These suggest partial mediation. The mediating hypotheses are partially supported. Besides, with the entry of innovative capacity, the significant effect of innovativeness on financial performance $(\beta=.428$, $p<.001)$ becomes non-significant $(\beta=-.041$, n.s. $)$. The result suggests full mediation. Innovativeness has no direct effect on financial performance, suggesting that its effect occurs entirely through its positive impact on innovative capacity. The mediating hypothesis is supported

\section{DISCUSSION}

This study verifies that the larger service firms in Taiwan comprehend the effects of the service economy. The results have theoretical and practical meanings. The suggestions are as follows. First, this study proves that the effects of market orientation, interaction orientation and innovativeness on innovative capacity are significant and positive. This result is consistent with the conceptual model proposed by Hurley and Hult (1998). It proved that innovation as the central mechanism by which organizations develop capabilities and adapt to their environments. To clarify the ability of market-oriented (that is, customer-led) and innovative capacity has an important interpretation. That is, it will benefit to develop capabilities of exploitation competence, exploration competence and learning transformative, if an organizational culture tends to create high quality customer of gathering market intelligence, inter-functional coordination. This proved that innovative capacity has significant and positive effect on both customer performance and financial performance. The result is consistent with Lichtenthaler (2009) who claimed absorptive capacity and the interactive marketing views of Ramani and Kumar (2008). It is worth noting that customer performance was less than the standard value. In addition to sample characteristics are affected. The other reason for this is that marketoriented requires the commitment of resources, and benefits often exceed the cost of the resources. Therefore, under conditions of stable market preferences, limited competition and booming economies, market orientation may not strongly relate (Kohli and Jaworski, 1990). Based on the above, a firm can improve organizational performance; except for enhance market orientation, interaction orientation and innovativeness, it must be important to include innovative capacity. Then, a firm can constitute complete complex capability.

Secondly, a great deal of marketing literature insists that innovation activities have a positive effect on firm performance. However, this study determined that innovative capacity is equally important to both customer performance and financial performance, taking into account the subsequent costs of the service industry (Anderson et al., 1997). Therefore services, except for the development 
of exploitation competence and exploration competence, it is necessary to use the customer competence. For example, attention to customers in positive word of mouth, gaining customer recognition and satisfaction are of great importance to the firm. Nevertheless, this study provides data to show that the effects of innovative capacity on both customer performance and financial performance are higher than the direct effect of innovative capacity on financial performance. The mediating effect of customer performance partially increases the total effect of innovative capacity on financial performance. This result is the same of the CRM perspective with regard to services marketing. This study deserves attention for academia and practice.

Thirdly, most services are intangible, heterogeneous, and inseparable (Parasuraman et al., 1985). Services need a flexible organizational culture to avoid the capability-rigidity. This study verifies the service economy in Taiwan, unlike previous studies, which only emphasize market-oriented (that is, customer-led) manufacturing. The overall performance of market-oriented (that is, customer-led) services through innovative capacity is highly effective, which use market orientation, interaction orientation and innovativeness as the antecedents of the innovative capacity. Organizational culture factors through innovative capacity on financial performance, the effect order are interaction orientation, market orientation and innovativeness. Therefore, it is important to understand that firms paying attention to customer value and interests can maintain the advantageous position in services. Therefore, the innovative capacity is both an important spanning and mediator to overall performance. Strengthening the innovation capability can improve the competitiveness of firms. To achieve this, Vargo and Lusch (2004) advocated the marketing concept of cocreation value on the firm or customer.

\section{LIMITATIONS AND FUTURE RESEARCH}

The results of this study may have the following bias. First, this paper conducted an empirical study of the service industries in Taiwan, by mailing questionnaires to conduct surveys of firms. Due to limited firm time, budget and limited number of replies, the study results may not be generalizable for use in other countries or industries. Future studies could analyze other countries or industries to make the results more generalizable. Secondly, the relationship between market orientation and performance may differ in economic or competitive environments in market-oriented (that is, customer-led) firms, and this study did not consider these environmental factors. Future studies could also integrate political, economical, legal and industrial factors. Thirdly, future empirical studies could examine the relative contribution of interaction orientation on the firm's positional advantage. Factors such as entrepreneurship, innovativeness, capacity to innovate, learning orientation and market orientation are all known to affect a firm's positional advantage (Hult and Ketchen, 2001; Hurley and Hult, 1998). Fourthly, innovative capacity is an important mediator for achieving cocreation value on firm/customer. The factors include competence exploitation, competence exploration and transformative learning. Future studies can continue to develop relations with the advanced CRM. Fifth, this study was a cross-sectional research and future studies can use a longitudinal method to observe the long-term relationships among variables.

\section{REFERENCES}

Abell DF (1999). Competing today while preparing for tomorrow. Sloan Manage. Rev., 40(3): 73-81.

Amabile TM, Conti R, Coon H, Lazenby J, Herron M (1996). Assessing the work environment for creativity. Acad. Manage. J., 39(5): 1154 1184.

Anderson EW, Fornell C, Mazvancheryl SK (2004). Customer satisfaction and shareholder value. J. Mark., 68(4): 172-185.

Anderson EW, Fornell C, Rust RT (1997). Customer satisfaction, productivity, and profitability: differences between goods and services. Mark. Sci., 16(2): 129-145.

Anderson JC, Gerbing DW (1988). Structural equation modeling in practice: a review and recommended two-step approach. Psychol. Bull., 103(3): 411-423.

Armstrong JS, Overton TS (1977). Estimating non-response bias in mail surveys. J. Mark. Res., 14(3): 396-402.

Atuahene-Gima K (2005). Resolving the capability: rigidity paradox in new product innovation. J. Mark., 69(4): 61-83.

Bagozzi RP, Yi Y (1988). On the evaluation of structural equation models. J. Acad. Mark. Sci., 16(1): 74-94.

Barney JB (1991). Firm resources and sustained competitive advantage. J. Manage., 17(1): 99-120.

Baron RM, Kenny DA (1986). The moderator-mediator variable distinction in social psychological research: conceptual and statistical considerations. J. Person. Soc. Psychol., 51(6): 1173-1182.

Burns T, Stalker GM (1961). The Management of Innovation. Tavistock Publishing, London.

Capron L, Hulland J (1999). Redeployment of brands, sales forces, and general marketing management expertise following horizontal acquisitions: a resource-based view. J. Mark., 63(2): 41-54.

Christensen CM, Bower JL (1996). Customer power, strategic investment, and the failure of leading firms. Strateg. Manage. J., 17(3): 197-218.

Cohen WM, Levinthal DA (1990). Absorptive capacity: a new perspective on learning and innovation. Adm. Sci. Q., 35(1): 128-152.

Day GS (1992). Marketing's contribution to the strategy dialogue. J. Acad. Mark. Sci., 20(4): 323-329.

Day GS (1994). The capabilities of market-driven organizations. J. Mark., 58(4): 37-52.

Deshpandé R, Farley JU, Webster Jr. FE (1993). Corporate culture customer orientation, and innovativeness in japanese firms: a quadrad analysis. J. Mark., 57(1): 23-37.

Deshpandé R, Webster FE Jr. (1989). Organizational culture and marketing: defining the research agenda. J. Mark., 53(1): 3-15.

Fornell C, Larcker DF (1981). Evaluating structural equation models with unobservable variables and measurement error. J. Mark. Res., 18(1): 39-50.

Garcia R, Calantone R (2002). A critical look at technological innovation typology and innovativeness terminology: a literature review. J. Prod. Innov. Manage., 19(2): 110-132.

Garud R, Nayyar PR (1994). Transformative capacity: continual structuring by intertemporal technology transfer. Strateg. Manage. J., 15(5): 365-385.

Hair Jr. JF, Black WC, Babin BJ, Anderson RE, Tatham RL (2006). Multivariate Data Analysis $\left(6^{\text {th }}\right.$ Ed.). Prentice Hall, Upper Saddle River, NJ. 
Hoekstra JC, Leeflang PSH, Wittink DR (1999). The customer concept: the basis for a new marketing paradigm. J. Market-Focused Manage., 4(1): 43-76.

Hogan JE, Lemon KN, Libai B (2003). What is the true value of a lost customer? J. Serv. Res., 5(3): 196-208.

Homburg C, Pflesser C (2000). A multiple-layer model of marketoriented organizational culture: measurement issues and performance outcomes. J. Mark. Res., 37(4): 449-462.

Hult GTM, Ketchen DJ (2001). Does market orientation matter? A test of the relationship between positional advantage and performance. Strateg. Manage. J., 22(9): 899-906.

Hunt SD, Morgan RM (1995). The comparative advantage theory of competition. J. Mark., 59(2): 1-15.

Hurley RF, Hult GTM (1998). Innovation, market orientation, and organizational learning: an integration and empirical examination. J. Mark., 62(3): 42-54.

Ireland RD, Hitt MA, Vaidyanath D (2002). Alliance management as a source of competitive advantage. J. Manage., 28(3): 413-446.

Jaworski B, Kohli AK (1993). Market orientation: antecedents and consequences. J. Mark., 57(3): 53-70.

Kirca AH, Jayachandran S, Bearden WO (2005). Market orientation: a meta-analytic review and assessment of its antecedents and impact on performance. J. Mark., 69(2): 24-41.

Kohli AK, Jaworski B (1990). Market orientation: the construct, research propositions, and managerial implications. J. Mark., 54(2): 1-18.

Lane PJ, Koka BR, Pathak S (2006). The reification of absorptive capacity: a critical review and rejuvenation of the construct. Acad. Manage. Rev., 31(4): 833-863.

Leonard-Barton D (1992). Core capabilities and core rigidities: a paradox in managing new product development. Strateg. Manage. J., 13(Special Issue): 111-125.

Levinthal DA, March JG. (1993). The myopia of learning. Strateg. Manage. J., 14(Special Issue): 95-112.

Lichtenthaler U (2009). Absorptive capacity, environmental turbulence, and the complementarity of organizational learning processes. Acad. Manage. J., 52(4): 822-846.

Lukas BA, Ferrell OC (2000). The effect of market orientation on product innovation. J. Acad. Mark. Sci., 28(2): 239-247.

March JG. (1991). Exploration and exploitation in organizational learning. Organ. Sci., 2(1): 71-87.

Menguc B, Auh S (2006). Creating a firm-level dynamic capability through capitalizing on market orientation and innovativeness. J. Acad. Mark. Sci., 34(1): 63-73.

Narver JC, Slater SF (1990). The effect of a market orientation on business profitability. J. Mark., 54(4): 20-35.

Nunnally JC (1978). Psychometric Theory. McGraw-Hill, New York, NY. O'Reilly CIII, Tushman ML (2004). The ambidextrous organization. Harv. Bus. Rev., 82 (4): 74-81.
Parasuraman A, Zeithaml VA, Berry LL (1985). A conceptual model of service quality and its implications for future research. J. Mark., 49(4): 41-50.

Prahalad CK, Ramaswamy V (2000). Co-Opting customer competence. Harv. Bus. Rev., 78(1): 79-87.

Ramani G, Kumar V (2008). Interaction orientation and firm performance. J. Mark., 72(1): 27-45.

Rayport JF, Jaworski BJ (2005). Best Face Forward. Harvard Business School Press, Boston, MA.

Reichheld F (2006). The Ultimate Question. Harvard Business School Press, Boston, MA.

Reinartz WJ, Krafft M, Hoyer WD (2004). The customer relationship management process: its measurement and impact on performance. J. Mark. Res., 41(3): 293-305.

Schein EH (1985). Organizational Culture and Leadership. JosseyBass, San Francisco, CA.

Shapiro BP (1988). What the hell is market-oriented?. Harv. Bus. Rev., 66(6): 119-125.

Slater SF, Narver JC (1995). Market orientation and the learning organization. J. Mark., 59(3): 63-74.

Slater SF, Narver JC (1998). Customer-led and market-oriented: let's not confuse the two. Strateg. Manage. J., 19(10): 1001-1006.

Slater SF, Narver JC (1999). Market-oriented is more than being customer-led. Strat. Manage. J., 20(12): 1165-1168.

Slotegraaf RJ, Moorman C, Inman JJ (2003). The role of firm resources in returns to market deployment. J. Mark. Res., 40(3): 295-309.

Srinivasan R, Lilien GL, Rangaswamy A (2002). Technological opportunism and radical technology adoption: an application to ebusiness. J. Mark., 66(3): 47-60.

Thompson VA (1965). Bureaucracy and innovation. Adm. Sci. Q., 5(1): 1-20.

Vargo SL, Lusch RF (2004). Evolving to a new dominant logic for marketing. J. Mark., 68(2): 1-17.

Yadav MS, Varadarajan PR (2005). Understanding product migration to the electronic marketplace: a conceptual framework. J. Retail., 81(2): 125-140.

Zahra SA, George G (2002). Absorptive capacity: a review, reconceptualization, and extension. Acad. Manage., 27(2): 185-203.

Zaltman G, Duncan R, Holbek J (1973). Innovations and Organizations. John Wiley and Sons, New York, NY.

Zollo M, Reuer JJ, Singh H (2002). Interorganizational routines and performance in strategic alliances. Organ. Sci., 13(6): 701-713. 